"This is an Accepted Manuscript of an article published by Taylor \& Francis in Archives of Physiology and Biochemistry on $16^{\text {th }}$ March 2016, available at

http://www.tandfonline.com/doi/full/10.3109/13813455.2016.1156706." 
REVISED

\section{IL-1 $\beta$ (interleukin-1 $\beta$ ) stimulates the production and release of multiple cytokines and chemokines by human preadipocytes}

Suliman Y. Alomar ${ }^{1}$, Alessandra Gentili ${ }^{2}$, Mohamed S. Zaibi ${ }^{2}$, Malgorzata A. KępczyńskaªndPaul Trayhurn ${ }^{1,2,3^{*}}$

${ }^{1}$ Zoology Department, College of Science, King Saud University, Riyadh, Saudi Arabia; ${ }^{2}$ Clore Laboratory, University of Buckingham, Buckingham, United Kingdom; ${ }^{3}$ Obesity Biology Unit, University of Liverpool, Duncan Building, Liverpool, United Kingdom

RUNNING TITLE: IL-1 $\beta$ stimulates cytokine and chemokine release by preadipocytes Keywords: Adipocytes, adipose tissue, gene expression, inflammation, protein arrays

*Correspondence should be addressed to:

Professor Paul Trayhurn, FRSE

Clore Laboratory

University of Buckingham

Hunter Street

Buckingham MK18 1EG, UK

Email: p.trayhurn@liverpool.ac.uk

Fax: $\quad$ +441280 820135 


\section{Abstract}

The effect of IL-1 $\beta$ on cytokine and chemokine production by human preadipocytes has been examined. Preadipocytes were incubated with IL-1 $\beta$ and cytokine and chemokine release measured at $24 \mathrm{~h}$ by protein arrays, while the expression of cytokine/chemokine genes was assessed by qPCR at 4 and $24 \mathrm{~h}$. IL-1 $\beta$ stimulated the secretion of multiple cytokines/chemokines, including IL-6, IL-8, IL-10, IL-13, MCP-4, TNF $\alpha$ and IP-10. IL-10 was not released by un-stimulated preadipocytes, while IL-6 exhibited the greatest response to IL-1 $\beta$ (453-fold increase). IL-16 and IL-12p40 did not respond to IL-1 $\beta$. qPCR demonstrated that IL1 $\beta$ markedly stimulated CCL3, CSF3 and CXCL10expression at $4 \mathrm{~h}$ (>900-fold mRNA increase). A time-course indicated that while CCL13 (encoding MCP-4) exhibited minimal basal expression in preadipocytes, expression increased progressively following differentiation. Human preadipocytes are highly sensitive to IL$1 \beta$, the cytokine stimulating a major inflammatory response in these cells similar to that in mature adipocytes.

147 words

\section{Introduction}

White adipose tissue, the expansion of which defines obesity, is composed of multiple cell types. The signature cell of the tissue, the mature adipocyte,both stores triacylglycerols and is a major endocrine and secretory cell. Multiple cytokines and chemokines are among the diverse range of proteins, or adipokines, released by white adipocytes, particularly when tissue mass increases with obesity (Frühbeck et al., 2001; Trayhurn et al., 2001; Rajala et al., 2004; Meijer et al., 2011; Trayhurn, 2013). The secretion of these, and other, inflammation-related factors is considered to underpin the development of the major obesity-associated diseases, including insulin resistance and the metabolic syndrome (Hotamisligil, 2006; Rosen \& Spiegelman, 2006; Bluher, 2009). Macrophages and other immune cells are key contributors to the inflammatory state of adipose tissue in obesity, this involving cross-talk between them and adipocytes (Weisberg et al., 2003; Xu et al., 2003; Pond, 2005; Bertola et al., 2012). Secretions from macrophages have been shown to induce an extensive pro-inflammatory response in white fat cells (O’Hara et al., 2009; Meijer et al., 2011).

Preadipocytes, the precursor cells of adipocytes, also have the potential to contribute to inflammation in white adipose tissue depots. Indeed, a substantial inflammatory response is induced following exposure to agents such as lipopolysaccharide (Chung et al., 2006; PoulainGodefroy \& Froguel, 2007; Meijer et al., 2011) and to secreted factors from macrophages 
(Lacasa et al., 2007; Keophiphath et al., 2009; Gao \& Bing, 2011; O'Hara et al., 2012). The effect of macrophage secretions involvesthe stimulation of the expression of several hundred genes, particularly those associated with inflammation, macrophage infiltration, lipid accumulation and the extracellular matrix, and reflect an overall pro-inflammatory and pro-fibrotic response (Lacasa et al., 2007; Keophiphath et al., 2009; O’Hara et al., 2012). One of the majorsignals from macrophages, IL-1000 (has been shown to be a key factor in the upregulation of IL-6 expressionand release in human preadipocytes(O’Hara et al., 2012). Similarly, IL-1DQDhas been found to stimulate the expression and release of specific matrix metalloproteinases (MMP1 and MMP3) in the same cells, this involving MAPK signalling (Gao \& Bing, 2011).

These observations raise the possibility that IL-1 $\beta$ has extensive effects on the release of inflammation-relatedfactorsbypreadipocytes, as we have recently demonstrated in differentiated human adipocytes (Alomar et al., 2015). In the present study, we have examined the extent to which IL-1 $\beta$ directly stimulates the production and secretion of cytokines and chemokines by human preadipocytes. Panels of protein arrays have been used to measure the release of these factors into the culture medium. The effect of IL-1 $\beta$ on the expression of selected cytokine/chemokine genes was also examined. The results are consistent with the view that preadipocytes are important inflammatory cells in white adipose tissue and that like adipocytes they are highly responsive to IL$1 \beta$.

\section{Materials and Methods}

\section{Cell culture}

Human fibroblastic preadipocytes (Ref C-12730, Lot 395Z024) were obtained from Promocell (Germany) together with the appropriate cell culture media. They were isolated from the subcutaneous adipose tissue of a female Caucasian donor, aged 44 years, with a BMI of 22. On receipt, the cells were plated $\left(5000\right.$ cells $\left./ \mathrm{cm}^{2}\right)$ in 12 -well plates and incubated in a proprietary growth medium (C-27410) containing 5\% fetal calf serum, hydrocortisone $(1 \mu \mathrm{g} / \mathrm{ml})$, heparin (90 $\mu \mathrm{g} / \mathrm{ml})$ and epidermal growth factor $(10 \mathrm{ng} / \mathrm{ml})$. The preadipocytes were grown to confluence (67 days) at which point they were used for experiments; the cells did not stain for lipid and in previous studies we have confirmed that, as expected, they do not express markers of adipocyte differentiation such as leptin.

In the main experiments, the preadipocytes were incubated with human recombinant IL1 $\beta$ (Sigma, UK) for either 4 or $24 \mathrm{~h}$, to determine the acute and long-term effects of the cytokine, as in our previous studies on mature adipocytes (Alomar et al., 2015). The dose of IL1 $\beta$ used $(2 \mathrm{ng} / \mathrm{ml}$ ) was the same as previously, and is based on studies which indicate a maximal, or near-maximal, 
response in human fat cells (Gao \& Bing, 2011). Control preadipocytes were incubated without IL-1 $\beta$. At the end of the incubation period the medium was removed, frozen, and stored at $-20^{\circ} \mathrm{C}$ until analysis. The preadipocytes were immediately washed with ice-cold PBS, frozen in TRIReagent (Sigma, UK) and stored at $-80^{\circ} \mathrm{C}$. Six sets of cells were used for each of the experimental groups.

In some cases, the preadipocytes were induced to differentiate by transfer for $72 \mathrm{~h}$ to a differentiation medium containing insulin $(0.5 \mu \mathrm{g} / \mathrm{ml})$, dexamethasone (400 $\mathrm{ng} / \mathrm{ml})$, IBMX (44 $\mu \mathrm{g} / \mathrm{ml}$ ) thyroxine (9 $\mathrm{ng} / \mathrm{ml}$ ) and ciglitazone $(3 \mu \mathrm{g} / \mathrm{ml}$ ), followed by Adipocyte Nutrition Medium, exactly according to the protocol described recently (Alomar et al., 2015). Some of the cells were taken every two days following the induction of differentiation and processed as for the preadipocytes prior to storage at $-80^{\circ} \mathrm{C}$. The medium was also taken and frozen at $-20^{\circ} \mathrm{C}$ until analysis.

\section{Protein arrays}

MSD assay kits (MesoScale Discovery, USA) were used to measure the release of cytokines and chemokines into the cell culture medium (Alomar et al., 2015). These sandwich ELISAs enable protein targets to be measured rapidly in small sample volumes. The following ten multi-spot plates were employed: V-PLEX Cytokine Panel 1 Human Kit (Ref : K15050D), V-PLEX Chemokine Panel 1 Human Kit (REF : K15047D) and V-PLEX Pro-inflammatory Panel 1 Human Kit (Ref : K15049D). The plates were pre-coated with capture antibodies on independent, well-defined spots and the assay was performed according to the manufacturer's instructions.

Proprietary Meso Scale software was used to analyse the data. The lowest limit of detection in the arrays was $0.01 \mathrm{pg} / \mathrm{ml}$ and this was for IL-18.

\section{RNA extraction}

Preadipocytes were homogenised in the TRI-Reagent in which they had been stored and total RNA extracted using RNeasy Micro Kits (QIAGEN, UK). The quantify and purity of the RNA was measured with a UV-Vis spectrophotometer (NanoDrop TM 1000, USA). The average absorbance ratios $(260 / 280 \mathrm{~nm}$ and $260 / 230 \mathrm{~nm})$ were close to 2.0 for all samples. The integrity of the isolated RNA was analysed with an Agilent 2100 Bioanalyser (Agilent Technologies, Germany), and the Integrity Number for RNA samples was approximately 10.

\section{Real-time PCR}

Total RNA was DNAse-treated with a TURBO-DNA-free ${ }^{\mathrm{TM}}$ kit (Ambion, Life Technologies ${ }^{\mathrm{TM}}$, USA) and $1 \mu \mathrm{g}$ was reverse transcribed using $\operatorname{Taqman}^{\circledR}$ reverse transcription reagents (Invitrogen ${ }^{\mathrm{TM}}$, Applied Biosystems, UK).Real-time PCR was performed with15-30ng of cDNA, in duplicates or triplicates, usingGene Expression Master Mix and predesigned TaqMan ${ }^{\circledR}$ Gene Assays consisting 
of specific Taqman ${ }^{\circledR}$ probes (Applied Biosystems ${ }^{\circledR}$, Life Technologies ${ }^{\mathrm{TM}}$, USA). Probes were obtained for the humanIL7, CCL3, CCL11, CCL13, CXCL10, CSF2 andCSF3 genes, andfor $A C T B$ ( $\square$-actin) as the control gene. PCR reactions were set up in duplex format where the FAM-labelled Taqman ${ }^{\circledR}$ probe for the gene of interest was mixed with the VIClabelled Taqman ${ }^{\circledR}$ probe for the control gene $(A C T B)$.

PCR amplification was performed using a real-time PCR detection system (ABI StepOneplus ${ }^{\mathrm{TM}}$, Applied Biosystems ${ }^{\circledR}$, Life Technologies ${ }^{\mathrm{TM}}$, USA) with a two-step thermal cycling: 950C for $10 \mathrm{~min}$, followed by 40 cycles of 950C for $15 \mathrm{sec}$ and 600C for $1 \mathrm{~min}$. All procedures were carried out in accordance with the manufacturer's recommendation. The data were analysed by the comparative 2- $\Delta \Delta C t$ method and expressed as fold-changes in the target gene normalized to the endogenous reference gene $(A C T B)$ in IL-1 $\beta$ treated adipocytes and related to the expression of the untreated samples (normalised such that the mRNA level in the untreated cells $=1.0$ ).

\section{Statistical analysis}

The statistical significance of differences between IL-1 $\beta$ treated and control cells in the protein array studies was assessed using Student's ttest.ANOVA with a Bonferroni post-test for selected columns was used in the case of the gene expression data.

\section{Results}

\section{Protein release}

Preadipocytes were taken immediately before they would normally be induced to differentiate into adipocytes, and incubated with IL-1 $\beta$ for 4 or $24 \mathrm{~h}$. The medium was used from the cells incubated for $24 \mathrm{~h}$ to measure the release of cytokines and chemokines so as to maximise the possibility that sufficient protein was present for analysis. Three different arrays were used such that in total the release of $>20$ proteins was investigated. All but one of the proteins on the arrayswas detected in the culture medium of untreated cells, indicating that eachis a normal secretory products of preadipocytes (Table 1). The sole protein which was not detectable in the medium of untreated cells was IL-10. Very low levels $(<1 \mathrm{pg} / \mathrm{ml})$ of IL-4, GM-CSF and

TNFCDwere evident. The most abundant proteins in the medium of the control preadipocytes were IL-8 and VEGF, which were present at concentration $>1 \mathrm{ng} / \mathrm{ml}$ and several hundred $\mathrm{pg} / \mathrm{ml}$, respectively.

Treatment with IL-1 $\beta$ resulted in marked increases in the amount present in the mediumfor most of the cytokines and chemokines (Table 1). Although IL-10 was not produced by the control cells, 
its production and release were induced by IL-100Dalbeit at low levels. For some factors, including IL-4, IL-7, IFND and TNFD, the minimal basal release was replaced by much more measurable quantities of the protein following IL- $1 \beta$ treatment. In the case of IL- 6 and IL- 8 , the concentration in the medium was at the $\mathrm{ng} / \mathrm{ml}$ level following exposure of the preadipocytes to IL-1 $\beta$, with the amount of IL-8 reaching $30 \mathrm{ng} / \mathrm{ml}$. For IL- 6 , this reflected a $>450$-fold increase in release from the preadipocytes; indeed, IL-1 1 stimulated the production and release of IL-6 proportionately more than for any other factor (no 'fold increase' can be given for IL-10 as this cytokinewas not detected in the medium from the control cells). Two further proteins, IP-10 and GM-CSF, exhibited a $>100$-fold increase in concentration in the medium following treatment with IL-10 (Table 1).

In contrast to the other proteins, the release of IL-16 and of IL-12p70 was not stimulated by IL-1 $\beta$ (Table 1$)$.

\section{Gene expression}

The effect of IL-1 on the expression of a selected group of cytokine and chemokine genes was also investigatedin human preadipocytes. The genes were primarily those encoding a sample of the multiple proteins examined in the array studies. The mRNA measurements were made at 4 and 24 h, to determine acute versus sustained responses to IL-1D. The expression of each of the genes, that is the mRNA level, was very low in the control, untreated cells, the Ct values being

33-36. There were, however, substantial increases with IL-10Din the level of the mRNAs forIL7, CCL3, CCL11, CCL13, CXCL10 and CSF3 (Fig 1); these mRNAs encode IL-7, MIP-1 $\alpha$, eotaxin1, MCP-4, IP-10 and and G-CSF (granulocyte colony stimulating factor), respectively. In the case of CCL3 the increase at $4 \mathrm{~h}$ was $>1,000$-fold relative to the control cells, and nearly 1,000-fold at the same time point for CXCL10 and CSF3. No signal was obeserved for CSF2 mRNA in the control cells at either 4 or $24 \mathrm{~h}$, but there was a substantial induction of CSF2 expression with IL-1 $\beta$ at 4 $\mathrm{h}$ (result not shown).

For each of the genes, with the exception ofCCL13, the mRNA level in IL-1D-treated preadipocytesrelative to the control cells was considerably higher at $4 \mathrm{~h}$ than at $24 \mathrm{~h}$ (Fig 1 ). This was particularly evident for CCXL10 where the nearly 1,000-fold increase in mRNA level at $4 \mathrm{~h}$ declined to $<100$-fold at $24 \mathrm{~h}$ (Fig 1).

Further analysis of several of the genes during the development of adipocytes indicated that the expression of CCL13 was highly differentiation-dependent. In preadipocytes, the basal 
expression of CCL13 was minimal, and it was only at day 4 post-induction of differentiation that substantial expression was evident; there was a progressive increase thereafter in CCL13 mRNA level with adipocyte development (Fig 2A). A similar pattern was apparent in the release into the medium of the encoded protein, MCP-4 (Fig 2B), the amount secreted at day 12 post-induction being 77-times greater than at day 0 (where it was barely detectable). The time course of IL-7 expression and release broadly paralleled that of CCL13/MCP-4, but greater expression and secretion was evident before differentiation with IL-7, and as a consequence the effects of differentiation were less marked (results not shown); IL7 mRNA level was 6.9-fold greater and IL7 protein release 10.3 fold greater in adipocytes at day 12 post-induction than in preadipocytes at day $0 . \mathrm{C}$

\section{Discussion}

The recruitment and activation of macrophages is considered to be central to the establishment of the inflammatory state that develops in white adipose tissue in obesity (Weisberg et al., 2003; Xu et al., 2003). Mature adipocytes are themselves important inflammatory cells, releasing a wide range of cytokines and chemokines as well as other inflammation-related factors following the appropriate stimulus (Trayhurn et al., 2001; Rajala et al., 2004; Meijer et al., 2011; Trayhurn, 2013). Secretory products from macrophages have been shown to elicit an extensive inflammatory response in fat cells (O'Hara et al., 2009; Meijer et al., 2011) and this can be mimicked, at least in part, by lipopolysaccharide, TNFODand IL-1 3 (Wang et al., 2005; Meijer et al., 2011; Alomar et al., 2015). An inflammatory response can also be elicited in preadipocytes (Lacasa et al., 2007; Keophiphath et al., 2009; Gao \& Bing, 2011; Meijer et al., 2011; O’Hara et al., 2012), which have been described as 'macrophage-like cells' (Cousin et al., 1999), and potentially in other cell typeswithin adipose depots. Inflammation in preadipocytes is activated by secretions from macrophages, as studies with macrophage-conditioned medium have demonstrated (Lacasa et al., 2007; Gao \& Bing, 2011; O'Hara et al., 2012). Thus there is extensive cross-talk between macrophages and the key cells within white fat.

Lipopolysaccharide, TNF $\alpha$ and IL-1DDhave each been shown to induce an inflammatory response in preadipocytes (Lacasa et al., 2007; Gao \& Bing, 2011; Meijer et al., 2011; O’Hara et al., 2012). In the case of IL-10 this pro-inflammatory cytokine isspecifically reported to stimulate the expression and secretion of IL-6 and of matrix metalloproteinases 1 and 3 (Gao \& Bing, 2011; O’Hara et al., 2012). IL-1DChas been shown to inhibit adipocyte differentiation in both 3T3-L1 
cells and human preadipocytes, but the concentration required appears much higher for the human cells (Simons et al., 2005; Lu et at., 2011; Gagnon et al., 2013).

The present study demonstrates that the effects of IL-1DDon human preadipocytes are extensive, protein arrays indicating that the factor stimulates the release of multiple cytokines and chemokines. Of the proteins on the arrays,IL-6, IP-10 and GM-CSF were the most responsive to IL-1DDin terms of the proportional increase in production. In some cases, including TNFDCDIL4 and IL-10, the basal secretion was at, or close to, the limit of detection of the arrays, but IL1DDinduced the release of readily measurable quantities of these cytokines. In practise, IL-10 was undetectable in the medium of un-stimulated preadipocytes.

The effects of IL-1D on preadipocytes are broadly similar to that which we recently reported for mature human adipocytes (Alomar et al., 2015). In adipocytes, as in preadipocytes, IL-6, GM-CSF, IL-10 and IP-10 were among the most responsive factors. Both IL-15 and VEGF were the least responsive; nevertheless, the amount of these factors released was increased 2-3-fold by IL-1 $\beta$. The secretion of IL-16 and IL-12p40 wasnot stimulated by IL-1DDin either adipocytes or preadipocytes. The main difference evident between preadipocytes and adipocytes (with similar experimental protocols) is that the release of MDC and IL-2 was stimulated rather more in mature fat cells than in their precursors - MDC 27.7-fold versus 2.9fold, IL-2 27.9-fold versus 3.7-fold, for adipocytes and preadipocytes respectively (Alomar et al., 2015).

In terms of the absolute amount of a specific protein released into the medium by unstimulated cells, VEGF and IL-8 were the most abundantin both preadipocytes and adipocytes.

In cells treated with IL-10 the quantitatively most important of the measured proteins in the medium from preadipocytes were IL-6 and IL-8, and these were also two of the most abundant secreted factors in the case of stimulated adipocytes (Alomar et al., 2015). For both types of cell, these proteins were present in the medium at ng levels. Thus there is a close similarity between mature adipocytes and preadipocytes not only in the responsiveness to IL-10D but also in the relative amounts of different cytokines and chemokines that are secreted. These comparisons assume, of course, that the secreted factors are released as such and are stable in the medium and not subject to significant degradation during the period that the cells are incubated.

We recently described MCP-4 as a novel adipokine, demonstrating release of the protein by human fat cells with the secretion being stimulated by IL-1DC(Alomar et al., 2015). MCP-4 is encoded by the CCL13 gene, and both CCL13 expression and the release of MCP-4 into the medium were observed in preadipocytes. CCL13 expression was in practise marginal in the basal state, but there 
was a marked induction in preadipocytes treated with IL-1D; this was paralleled by a substantial stimulation in the release of MCP-4 protein into the medium. Time-course studies during differentiation showed that as preadipocytes differentiate and develop into mature fat cells there is a progressive increase in CCL13 gene expression. This suggest that CCL13 expression is in effect a late marker of differentiation, similar to factors such as leptin.MCP-4, which is also known as chemokine (C-C motif) ligand 13, is a chemotactic factor that attracts macrophages, monocytes, $\mathrm{T}$ lymphocytes, basophils and eosinophils, and which is involved in a number of chronic inflammatory diseases (Mendez-Enriquez \& Garcia-Zepeda, 2013).

In contrast to the other genes examined, the expression of CCL13 did not decrease between 4 and 24 h of treatment with IL-1 $\mathrm{I}$ relative to control cells; indeed there was a marginal increase. The response to IL-10Dwith respect to expression of the CCL11 and of CXCL10 genes, in particular, showed a substantial reduction at $24 \mathrm{~h}$ compared with $4 \mathrm{~h}$. These genes clearly respond acutely, though transitorily, to stimulation by IL-10D while there was a sustained response in the case of CCL13. The sustained effect may indicate that other factors which accumulate following treatment with IL-10Dmay play a role in stimulating CCL13 expression in preadipocytes.

\section{Conclusions}

The present study demonstrates that preadipocytes are highly responsive to IL-1 $\beta$, the proinflammatory cytokine inducing increased production of a wide range of cytokines and chemokines. Many of these factors, some of which are pro- and others anti- inflammatory, are also released by preadipocytes in the basal, un-stimulated state. There are close parallels between both preadipocytes and mature adipocytes in the ability with which they are able to release inflammation-related factors. Preadipocytes are endocrine cells, paralleling in some respects adipocytes themselves - although preadipocytes are generally considered not to express and release the signature adipocyte hormones leptin and adiponectin. Exposure to hypoxic conditionsdoes, however, induce the expression and secretion of leptin by these precursor cells(Wang et al., 2008). Cross-talk between macrophages and preadipocytes, in addition to that between the immune cells and adipocytes, is likely to be a component of the inflammatory condition that is initiated in white adipose depots in obesity. 


\section{Declarations of interest}

The authors gratefully acknowledge the financial support of the Distinguished Scientist Fellowship Programme at King Saud University. The authors also declare that they have no conflicts of interest in regard to this study.

\section{References}

Alomar SY, Zaibi MS, Kepczynska MA, Gentili A, Alkhuriji A, Mansour L, Dar JA, Trayhurn P. (2015). PCR array and protein array studies demonstrate that IL-1 $\beta$ (interleukin$1 \beta$ ) stimulates the expression and secretion of multiple cytokines and chemokines in human adipocytes. Arch Physiol Biochem, in press.

Bertola A, Ciucci T, Rousseau D, Bourlier V, Duffaut C, Bonnafous S, Blin-Wakkach C, Anty R, Iannelli A, Gugenheim J, Tran A, Bouloumié A, Gual P, Wakkach A. (2012). Identification of adipose tissue dendritic cells correlated with obesity-associated insulinresistance and inducing Th17 responses in mice and patients. Diabetes 61:2238-47.

Blüher M. (2009). Adipose tissue dysfunction in obesity. Exp Clin Endocrinol Diabetes 117:241-50.

Chung S, LaPoint K, Martinez K, Kennedy A, Boysen Sandberg M, McIntosh MK. (2006). Preadipocytes mediate lipopolysaccharide-induced inflammation and insulin resistance in primary cultures of newly differentiated human adipocytes. Endocrinology 147:5340-51.

Cousin B, Munoz O, Andre M, Fontanilles AM, Dani C, Cousin JL, Laharrague P, Casteilla L, Penicaud L. (1999). A role for preadipocytes as macrophage-like cells. FASEB J 13:30512 .

Frühbeck G, Gómez-Ambrosi J, Muruzabal FJ, Burrell MA. (2001). The adipocyte: a model for integration of endocrine and metabolic signaling in energy metabolism regulation. Am J Physiol Endocrinol Metab280:E827-E47.

Gagnon A, Foster C, Landry A, Sorisky A. (2013). The role of interleukin $1 \beta$ in the antiadipogenic action of macrophages on human preadipocytes. J Endocrinol 217:197-206.

Gao D, Bing C. (2011). Macrophage-induced expression and release of matrix metalloproteinase 1 and 3 by human preadipocytes is mediated by IL-1 $\beta$ via activation of MAPK signaling. J Cell Physiol 226:2869-80.

Hotamisligil GS. (2006). Inflammation and metabolic disorders. Nature 444:860-67.

Keophiphath M, Achard V, Henegar C, Rouault C, Clement K, Lacasa D. (2009). Macrophagesecreted factors promote a profibrotic phenotype in human preadipocytes. Mol Endocrinol 23:11-24. 
Lacasa D, Taleb S, Keophiphath M, Miranville A, Clément K. (2007). Macrophage-secreted factors impair human adipogenesis: involvement of proinflammatory state in preadipocytes. Endocrinology 148:868-77.

Lu C, Kumar PA, Fan Y, Sperling MA, Menon RK. (2010). A novel effect of growth hormone on macrophage modulates macrophage-dependent adipocyte differentiation. Endocrinology 151:2189-99.

Meijer K, de Vries M, Al-Lahham S, Bruinenberg M, Weening D, Dijkstra M, Kloosterhuis N, van der Leij RJ, van der Want H, Kroesen BJ, Vonk R, Rezaee F. (2011). Human primary adipocytes exhibit immune cell function: adipocytes prime inflammation independent of macrophages. PLoS One 6:e17154.

Mendez-Enriquez E, Garcia-Zepeda EA. (2013). The multiple faces of CCL13 in immunity and inflammation. Inflammopharmacol 21:397-406.

O’Hara A, Lim F-L, Mazzatti D, Trayhurn P. (2009). Microarray analysis identifies matrix metalloproteinases (MMPs) as key genes whose expression is up-regulated in human adipocytes by macrophage-conditioned medium. Pflügers Archiv EurJPhysiol 458:1103-14.

O’Hara A, Lim F-L, Mazzatti DJ, Trayhurn P. (2012). Stimulation of inflammatory gene expression in human preadipocytes by macrophage-conditioned medium: Upregulation of IL-6 production by macrophage-derived IL-1 $\beta$. Mol Cell Endocrinol 349:239-47.

Pond CM. (2005). Adipose tissue and the immune system. Prost Leuk Essent Fatty Acids 73:17-30.

Poulain-Godefroy O, Froguel P. (2007). Preadipocyte response and impairment of differentiation in an inflammatory environment. Biochem Biophys Res Commun 356:662-67.

Rajala MW, Qi Y, Patel HR, Takahashi N, Banerjee R, Pajvani UB, Sinha MK, Gingerich RL, Scherer PE, Ahima RS. (2004). Regulation of resistin expression and circulating levels in obesity, diabetes, and fasting. Diabetes 53:1671-79.

Rosen ED, Spiegelman BM. (2006). Adipocytes as regulators of energy balance and glucose homeostasis. Nature 444:847-53.

Simons PJ, van den Pangaart PS, van Roomen CP, Aerts JM, Boon L. (2005). Cytokine-mediated modulation of leptin and adiponectin secretion during in vitro adipogenesis: evidence that tumor necrosis factor-aand interleukin-1D-treated human preadipocytes are potent leptin producers. Cytokine 32:94-103.

Trayhurn P, Beattie JH. (2001). Physiological role of adipose tissue: white adipose tissue as an endocrine and secretory organ. Proc Nutr Soc 60:329-39.

Trayhurn P. (2013). Hypoxia and adipose tissue function and dysfunction in obesity. Physiol Rev 93:1-21. 
Wang B, Jenkins JR, Trayhurn P. (2005). Expression and secretion of inflammation-related adipokines by human adipocytes differentiated in culture: Integrated response to TNF- $\alpha$. $A m$ J Physiol Endocrinol Metab 288:E731-E40.

Wang B, Wood IS, Trayhurn P. (2008). Hypoxia induces leptin gene expression and secretion in human preadipocytes: differential effects of hypoxia on adipokine expression by preadipocytes. J Endocrinol 198:127-34.

Weisberg SP, McCann D, Desai M, Rosenbaum M, Leibel RL, Ferrante AW, Jr. (2003). Obesity is associated with macrophage accumulation in adipose tissue. J Clin Invest 112:1796-808.

Xu H, Barnes GT, Yang Q, Tan G, Yang D, Chou CJ, Sole J, Nichols A, Ross JS, Tartaglia LA, Chen H. (2003). Chronic inflammation in fat plays a crucial role in the development of obesity-related insulin resistance. J Clin Invest 112:1821-30. 
Table 1. Effect of IL-1 $\beta$ on cytokine and chemokine secretion from human white preadipocytes in culture

\begin{tabular}{|c|c|c|c|}
\hline Protein & $\begin{array}{l}\text { Control } \\
(\mathrm{pg} / \mathrm{ml})\end{array}$ & $\begin{array}{l}\text { IL-1 } \beta \text { treated } \\
(\mathrm{pg} / \mathrm{ml})\end{array}$ & Fold-change with IL-1 $\beta$ \\
\hline IL-10 & ND & $2.53 \pm 0.23$ & - \\
\hline IL-6 & $7.71 \pm 0.91$ & $3,491 \pm 66^{* * *}$ & 452.8 \\
\hline IP-10 & $23.6 \pm 3.7$ & $2,862 \pm 253^{* * *}$ & 121.3 \\
\hline GM-CSF & $0.884 \pm 0.294$ & $100 \pm 4^{* * *}$ & 113.5 \\
\hline MIP-1 $\beta$ & $6.32 \pm 0.83$ & $574 \pm 99 * *$ & 90.9 \\
\hline IL-13 & $2.82 \pm 0.19$ & $150 \pm 20^{* * *}$ & 53.3 \\
\hline TNF $\alpha$ & $0.492 \pm 0.129$ & $15.2 \pm 1.1 * * *$ & 30.9 \\
\hline IL-8 & $1,049 \pm 207$ & $30,244 \pm 4,183^{* * *}$ & 28.8 \\
\hline IL12-p70 & $0.241 \pm 0.053$ & $4.28 \pm 0.41 * * *$ & 17.8 \\
\hline MCP-4 & $4.93 \pm 0.83$ & $86.7 \pm 12.9 * * *$ & 17.6 \\
\hline $1 \mathrm{FN} \gamma$ & $1.26 \pm 0.27$ & $20.2 \pm 1.5^{* * *}$ & 16.0 \\
\hline Eotaxin & $10.1 \pm 0.8$ & $135 \pm 44 *$ & 13.5 \\
\hline IL-7 & $1.69 \pm 0.13$ & $20.3 \pm 1.7^{* * *}$ & 12.0 \\
\hline IL-4 & $0.229 \pm 0.044$ & $2.01 \pm 0.16^{* * *}$ & 8.78 \\
\hline Eotaxin-3 & $10.2 \pm 1.6$ & $55.7 \pm 11.9^{*}$ & 5.47 \\
\hline IL-2 & $11.6 \pm 0.7$ & $42.7 \pm 2.4^{* * *}$ & 3.69 \\
\hline MDC & $24.3 \pm 4.8$ & $70.6 \pm 3.2 * * *$ & 2.91 \\
\hline IL-15 & $9.13 \pm 0.63$ & $19.9 \pm 0.38^{* * *}$ & 2.17 \\
\hline VEGF & $301 \pm 24$ & $620 \pm 59 * *$ & 2.06 \\
\hline IL-12p40 & $2.83 \pm 0.51$ & $3.07 \pm 0.40^{\mathrm{NS}}$ & 1.08 \\
\hline IL-16 & $53.9 \pm 11.0$ & $45.7 \pm 5.2^{\mathrm{NS}}$ & 0.848 \\
\hline
\end{tabular}

Human preadipocytes were incubated in the presence or absence of human recombinant IL-1 $\beta$ (2 $\mathrm{ng} / \mathrm{ml}$ ). Protein arrays were used to screen the effect of IL-1 $\beta$ on cytokine and chemokine secretion into the medium over $24 \mathrm{~h}$. The results ( $\mathrm{pg} / \mathrm{ml}$ medium) are the means \pm SE for 5-6 groups of adipocytes. ${ }^{* * *} P<0.0001,{ }^{* *} P<0.001, * P<0.02$ compared with control, untreated cells. NS, not significant $(P>0.05)$. The lowest detection limit was for IL-8 $(0.01 \mathrm{pg} / \mathrm{ml})$.

\section{Legends to Figures}


Figure 1. Effect of IL-1 $\beta$ on the expression of cytokine and chemokine genes in human preadipocytes. Human preadipocytes were incubated in the presence or absence of human recombinant IL-1 $\beta$ ( $2 \mathrm{ng} / \mathrm{ml})$ for 4 or $24 \mathrm{~h}$. The results show the fold-changes in mRNA level for preadipocytes treated with IL-1 $\beta$ compared with controls (controls normalised to 1.0) at each time point. No signal was detected for CSF3 in the control cells at $24 \mathrm{~h}$ so the IL-1 $\beta$ treated cells have been related to the controls at $4 \mathrm{~h}$. The fold-changes are mean values \pm SE (bars) for 4-6 experiments at both time points. ${ }^{* * *} P<0.0001,{ }^{*} * P<0.001$, compared with control, untreated cells. The proteins encoded by each of the genes examined were: CCL3, MIP-1D; CC11, eotaxin; CCL13, MCP-4; CXCL10, IP-10; CSF3, granulocyte colony stimulating factor.

Figure 2. Expression of theCCL13 gene (A)and release of the encoded MCP-4 protein (B) during the differentiation of human preadipocytes into adipocytes. Differentiation was induced at day 0 and cells and medium taken every 2 days; from day 4, the cells contained multiple lipid droplets and stained positively with Oil red $\mathrm{O}$. The results, which are expressed relative to the values at day 0 (set as 1.0), are mean values \pm SE (bars) for 3-4 experiments at each time point. 
Figure 1
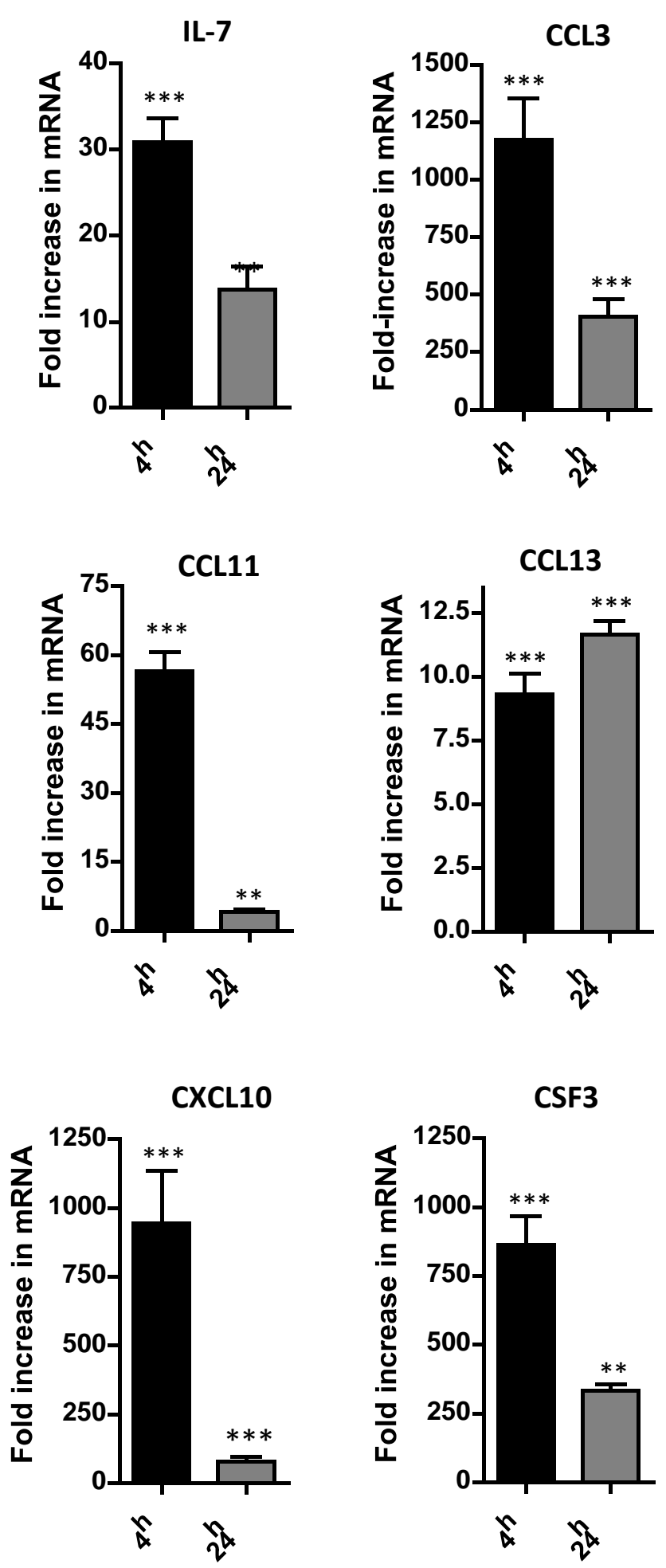
Figure 2
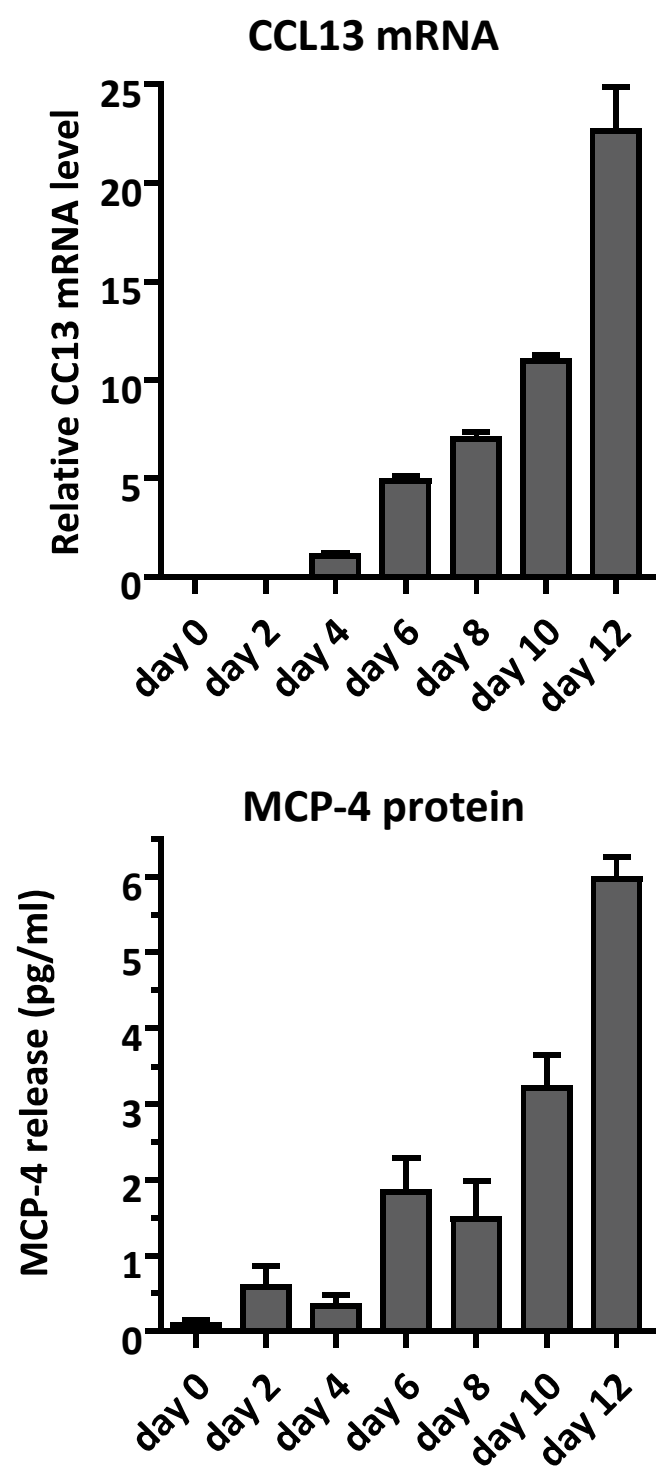

Days post-induction 